Historic, Archive Document

Do not assume content reflects current scientific knowledge, policies, or practices. 


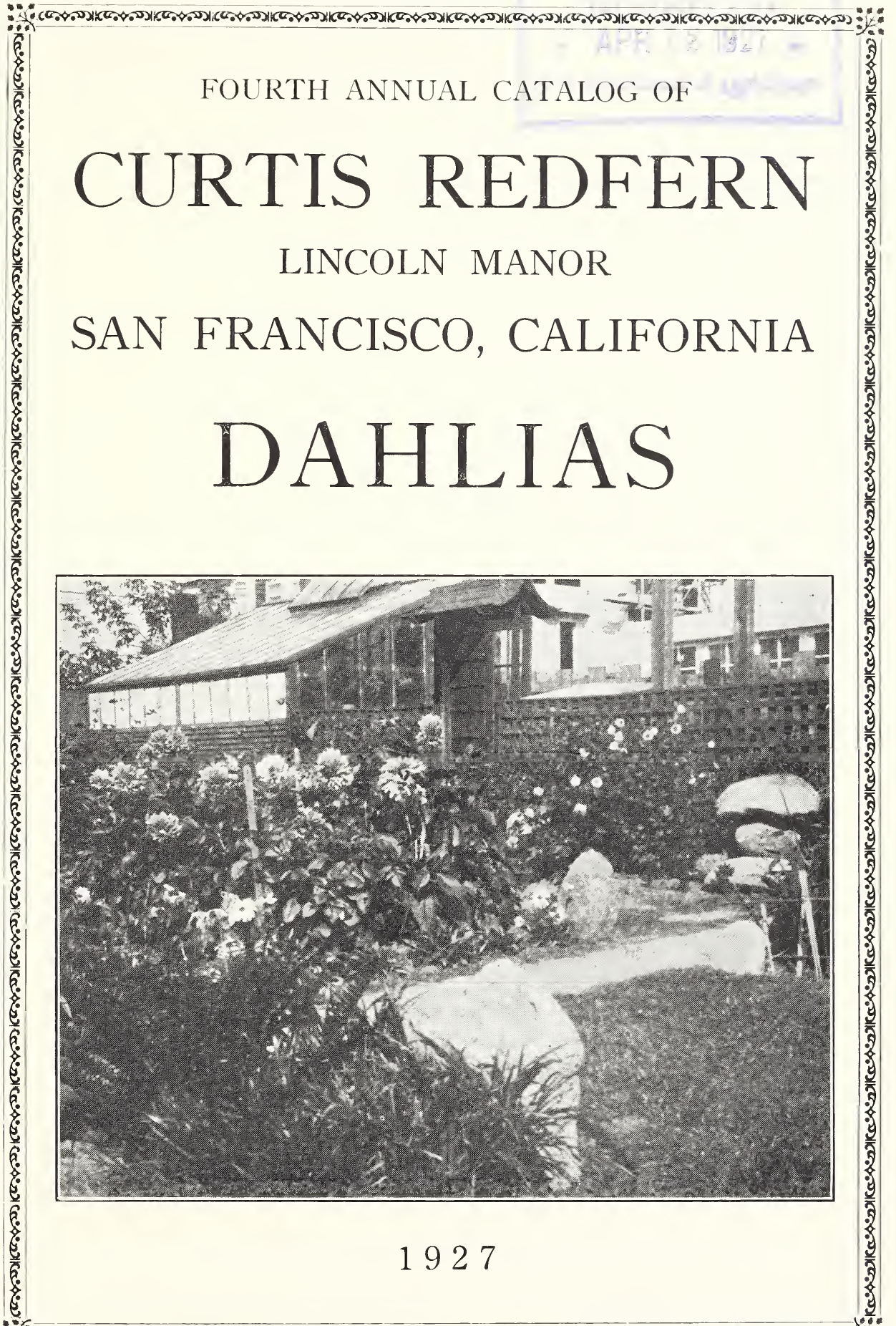




\section{THE BARBARA REDFERN DAHLIA}

"Can you imagine a ten inch decorative bloom on a four foot stem hauled five hundred miles and at the end of three days not only as fresh as when cut, but you couldn't shake a petal or jar a neck? A coral pink face with a coral red reverse. (Ridgeway's Color Chart under artificial light.) That's Barbara Redfern, as shown by Curtis Redfern of Lincoln Manor, San Francisco.

“This flower rates 98 against Jersey's Beauty at 91, and I must call it even better than Mrs. Carl Salbach, the finest dahlia I have ever seen, exhibition and commercial."

GEORGE V. WARREN.

Extract from Oct., 1926, Bulletin of

The Dahlia Society of Southern California. 


\section{INTRODUCTIONS}

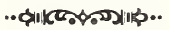

Barbara Redfern, an enormous rosy gold decorative. May 1st delivery, strong field grown tubers, (Redfern) $\$ 10.00$

Two years ago I asked my friend, Mrs. Elizabeth Lymbery, of the Bessie Boston Dahlia Farm at San Mateo, California, to grow this variety and pass upon its merits. Mrs. Lymbery has originated more gold medal and prize winning dahlias than any other grower in the world, and I know you will value her expert opinion. I asked her to write the description for this catalog; it is as follows:

Barbara Redfern. "One of California's best introductions, a new dahlia, which, as the years pass will

rank as a standard. New dahlias are arriving every season, many of which are heralded as the greatest dahlias of the world. Their lives are short in large numbers of cases, but Barbara Redfern is a decorative which will have a long life. After you have once grown it, you will always grow it. The people who want size above everything else, will delight in it. The flower lovers who crave beautiful coloring, will rejoice in it. The big majority of dahlia lovers who insist on a stiff stem, and a robust plant which will bloom early and profusely, will welcome this addition to their collection. Color is a wondrous combination of old rose and old gold. The outside of the petals is dull gold, the reverse is delicate old rose. Petals are very long and of medium width. Owing to their formation both colors show at once. Flower is of mammoth size and great depth, and borne on a heavy, stiff stem, which never bends, but carries the big flower upright at all seasons. The bush is a clean, healthy grower, blossoms early and blooms continuously. Flowers last four or five days after being picked. Has been grown with great success for two seasons in the warm sunshine of San Mateo." Mrs. Charles H. Stout of Short Hills, New Jersey, has also grown the Barbara Redfern for two years and it was a first prize winner at the Short Hills Show in 1925. Another friend in comparing 
it with several gold medal varieties said it was easily a $\$ 50$ variety, and Mr. Alexander Waldie, the dean of Pacific Coast dahlia growers, tried to prevail upon me to list it at $\$ 15$ at least.

Our 1926 San Francisco Show was two weeks too early for me and I had but three blossoms of the Barbara Redfern to show. The beauty of the eleven inch flowers, however, attracted growers and amateurs alike.

A few weeks later a large bunch made the trying 500-mile trip to Los Angeles where they created a sensation at the show in the Biltmore Hotel. At the end of the show, although the weather had been unusually hot, they seemed more beautiful than at the beginning and were so fresh that the show manager asked permission to send them to a friend at Catalina Island, more than 50 miles away.

Delphia a medium sized decorative the center of which is a deep strawberry red, gradually becoming a golden tan at the tips of the petals. (Redfern) Field grown tubers, $\$ 5.00$ Delphia has every desirable dahlia quality but size. Compared with other California giants its average of seven inches places it in the medium-size class. It is named in honor of Miss Delphia Riley, the charming proprietor of the Palace Hotel Flower Shop, who considers it a superb florist's dahlia. In the garden it is a delight, blooming as it does on long strong stems above the full sturdy bush, the blossoms facing upwards. For use in autumn colored baskets it is invaluable, filling the break between the golds and the reds. It keeps its center until frost.

I grow dahlias primarily for my own pleasure. If a variety proves unsatisfactory it is dug at once and junked, therefore, in the following list of Standard Varieties there is not a dahlia that is not desirable whether it is listed at 75 cents or $\$ 10$. The originator's name is in parenthesis. 
Decorative Dahlias are double flowers, full to the center early in the season, flat rather than ball shaped, with broad, flat, more or less loosely arranged petals with the tips broad or rounded.

Cactus Dahlias English and American types have flowers resembling chrysanthemums. The Hybrid type is fully double; the petals are shorter than the English and American types, and are broad, flat, and recurved or twisted.

Peony Dahlias are semi-double; show an open center, and usually have an inner row of petals that are curved or twisted.

Al Koran

Decorative. A glorious big bright yellow flower, deepening to amber at the centre. (Davies) $\$ 2.00$

Amber Glow English Cactus, Bright yellow, deepening to pale orange at the centre. (Boston) $\$ 1.00$

Amun Ra Decorative. A stunning flower of copper and orange with a reflex of scarlet. (Seal) $\$ 1.00$

Arganaut Decorative. Gold with an apricot centre and a suffusion of the same shade. (Boston) $\$ 3.00$

Arrow of Decorative. Pure gold, deepening in the centre Gold and shading to a golden apricot and amber at the outer petals. (Seal) $\$ 2.50$

Arthur American Cactus. Flesh or blush pink. White Twitchett in San Francisco. (Boston) $\$ 1.00$

English Cactus. Orange with a white edge, Ballet Girl some flowers will be all orange, others white. (Boston) $\$ 1.50$ 
Barbara

Redfern

Bazaar

Beau

Brummel

Belvedere

Betty Bird

Black Jack

California

Enchantress

California

Superba

Chronicle

Champagne

Cinderella

Cliff Craggs Cooper, W. E. $\begin{aligned} & \text { Decorative. A clear true pink. (Boston) } \\ & \$ 1.50\end{aligned}$

Decorative, See Description on page three. $\$ 10.00$

Decorative. California sunset shades, soft chrome yellow overlaid with red. (Boston) $\$ 2.00$

Decorative. Pure royal purple. (Boston) $\$ 2.50$

Decorative. Deep red. Very large. Fine cut flower as well as exhibition variety. (Asmus) $\$ 5.00$

Hybrid Show. Glowing rose pink with a suggestion of yellow at base of petals. (Seal) $\$ 5.00$

Decorative. Deepest maroon. (DresslerHodgens) $\$ 2.50$

Hybrid Cactus. Pale pink. (Boston) $\$ 1.00$

Decorative. Delicate shade of pink without any blue tone, and shades gradually to a white centre. (Wintjen-Boston) $\$ 2.50$

Decorative. Deep red. (Westilius) $\$ 5.00$

Decorative. Warm autumn shades, varying from burnished copper to a dull golden champagne and chamois. (Boston) $\$ 2.50$

Hybrid Cactus. Pale salmon, or fawn pink, shading to a tan centre. (Boston) $\$ 3.00$ Decorative. Brilliant orange red. Very fine. (Asmus) $\$ 5.00$

Hybrid Cactus. American Beauty Rose shades. (Boston) $\$ 2.00$

Decorative. Deepest shade of cerise at the

Davies, J. W. centre graduating to a lighter tint. (Boston) $\$ 2.50$ 
Delphia

De Young,

M. H.

Dr. Tevis

Earle Williams

\section{Elberon \\ Beauty \\ Emily Renwick}

Empire

Faith Garibaldi

Galatea

General Haig Show. Scarlet. (Kettlewell) \$1.00

Gladys Bates American Cactus. Tan, with a reverse of rose (Boston) $\$ 1.50$

Halvella

Ian

Insulinde

Islam Patrol

Jean Chazot

Decorative. Strawberry shades of red. (Redfern) See page four for description. $\$ 5.00$

Decorative. Pure old gold. (Boston) $\$ 5.00$

Decorative. A blend of copper, old rose and old gold. (Pelicano) 75c

Decorative. An immense scarlet, tipped white. (Doolittle) $\$ 1.50$

Decorative. Old gold. (Fisher-Masson) $\$ 2.50$

Decorative. Beautifully formed flower;color iridescent rose pink (Stout) $\$ 2.00$

American Cactus. Raspberry red. Very fine. (Boston) $\$ 2.00$

Decorative. Silvery pink. (GaribaldiBoston) $\$ 5.00$

Soft yellow embellished with a suffusion of pink on outer petals. A gold medal variety. (Boston) $\$ 2.50$

Decorative. Old rose, slightly brighter than salmon. (McWhirter) $\$ 2.00$

Cactus. Clear yellow, gradually shading pink on the outer rows of petals. (Boston) $\$ 7.50$

Decorative. Rich golden orange. \$1.50

Hybrid decorative. Brilliant red tipped pure gold. (Davies) $\$ 3.00$

American cactus. Golden bronze suffused with nasturtium red. $\$ 1.00$ 
Jersey's Beauty

Decorative. Enchanting shade of pink.

Jersey's

Caprice (Waite) $\$ 2.00$

Jersey's

Jewel

Autumn colors, principally old gold. (Waite) $\$ 10.00$

Decorative. Orchid or mauve pink. (Waite) $\$ 5.00$

Jersey's

Monarch

Decorative. Deep salmon, shading to a yellow center. (Waite) $\$ 5.00$

Jersey's

Queen

Decorative. Pale lavender. (Waite) $\$ 2.00$

Jersey's

Sovereign

Decorative. Glorious orange gold. (Wraite) $\$ 3.00$

Decorative. American Beauty Rose, One

Kitty Dunlap of the finest dahlias in commerce. (Boston) $\$ 1.50$

Koh-I-Noor Hybrid cactus. Maroon, at times so dark as to be nearly black. (Boston) $\$ 2.50$

\section{Leah}

Gleadell

Decorative. Copper illuminated with gold. (Gleadell) $\$ 3.00$

Logan's White Decorative. White. (Logan) $\$ 1.50$

Lolita

Velasco

Mac Gregor

Mariposa

Miss Worn

Mrs. Asmus

Mrs. Estes
American cactus. White. (Boston) $\$ 2.00$

Hybrid cactus. Nopal or soft red. (Mastick) $\$ 2.50$

Hybrid cactus. Lavender pink. (Boston) $\$ 2.50$

Decorative. Burnished copper suffused with old rose. (Boston) $\$ 1.50$

Decorative. Pink. Medium sized flower. (Asmus) $\$ 2.50$

Hybrid cactus. White. (Estes) $\$ 1.00$ 
Mrs. Eleanor Martin

Mrs. Carl

Salbach

Nichu

Oriole

Pennant

Pride of San Francisco

Rollo Boy

Rookwood

Rosa Nell

Sanhican

Darky

Serpolette

Shudow's

Lavender

Sunny California

Susan Tevis

Tommy

Atkins

Trentonian
Decorative. Mulberry. The petals are a peculiar rose tint with a reverse of violet. (Pelicano) $\$ 4.00$

Decorative. Mauve pink shading to white. (Salbach) $75 \mathrm{c}$

Hybrid cactus. Yellow. Very fine. (Boston) $\$ 5.00$

Peony. Burnt orange, red, and yellow. (Burns) $\$ 1.00$

English cactus. Coral and orange. $\$ 1.00$

Decorative. Brilliant salmon pink. (McWhirter) Medium sized flower. $\$ 2.50$

Hybrid cactus. Pale apricot yellow. Very fine. (Pelicano) $\$ 3.00$

Decorative. Pure bright cerise rose. (Boston) $\$ 3.00$

Decorative. Clear rose. (Broomall) 75c

Decorative. Deep purplish Bordeaux crimson (Fisher-Masson) $\$ 3.00$

Decorative. Deep lavender. (Boston) $\$ 1.50$

Decorative. Silvery lavender slightly shading to white. A gold medal variety. (Boston) $\$ 2.00$

Decorative. Old gold suffused with various shades of red. (Seal) $\$ 2.50$

Decorative. Lilac blue in color. (Boston) $\$ 3.00$

Decorative. Flaming scarlet. The most colorful dahlia in the list. (Boston) $\$ 2.50$

Decorative. Old gold, amber, and coppery bronze in color. (Fisher \& Masson) $\$ 3.50$ 
U. S. A.

Wizard Of $\mathrm{Oz}$

Warren Seipp

Zante
Decorative. Deep orange. $\$ 1.50$

Decorative. Salmon rose shading to yellow. (Doolittle) $\$ 3.00$

Cactus. Red. (Vincent) $\$ 2.00$

Hybrid cactus. Gold, heavily suffused with apricot pink. (Boston) $\$ 5.00$

For beginners I offer a remarkably fine collection of twelve dahlias selected from this catalog for $\$ 15.00$. At list prices these twelve dahlias would be more than twice the cost of the collection.

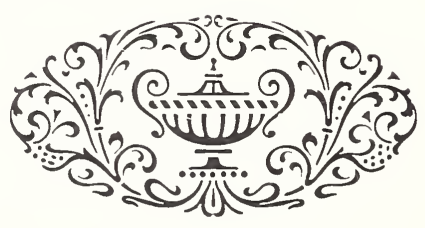



